\title{
STOLAC FROM A HAMLET TO AN OTTOMAN TOWN AND ISLAMIC CULTURAL CENTRE: A CONTRIBUTION TO THE HISTORY OF URBAN DEVELOPMENT IN BOSNIA-HERZEGOVINA
}

\author{
Machiel KIEL \\ Emeritus Professor of Islamic Architecture and Civilization \\ Honorary Member of the Turkish Historical Association \& Senior Research Fellow of the NIT \\ machiel.kiel@googlemail.com
}

\begin{abstract}
This contribution discusses changes among the typical settlements of the Balkans during the 15 th century when Ottomans ruled the region. The land was scattered with mountaintop castles of powerful feudal lords, large landowning monasteries, and peasants living in feudal servitude. Towns with an urban structure, hosting a population living from crafts and trade, and a proper administration mushroomed all over the region. This change is studied through the example of the city Stolac (pronunciation: Stolats) in BosniaHerzegovina. It shows the alteration of the medieval settlements from a hamlet to an Ottoman town and Islamic cultural centre.

The study analyses historical and demographical data, in combination with the architectural heritage of Stolac, benefiting from rich archival material published by the author, fed by travellers' description and fieldwork results. The case study of Stolac supports the discussion and related theories about the emergence of towns across the Balkans at the arrival of Ottomans.
\end{abstract}

\section{KEYWORDS}

Stolac; Bosnia-Herzegovina; Balkans; Ottoman city; Islamic cultural centre; Islamic architecture.

\begin{abstract}
الملخص
تناقش هذه المساهمة التغييرات التي شهدتها المستوطنات

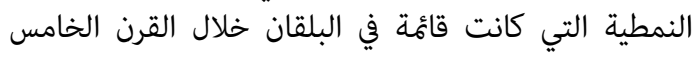

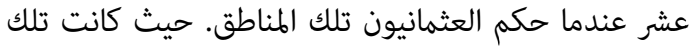

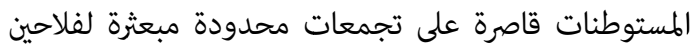

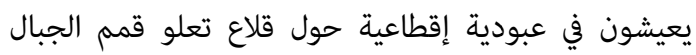
يملكها أمراء إقطاعيون أقوياء، أو أديرة تشغل ملكية كبية إعبية.

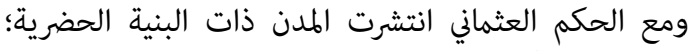

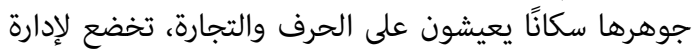

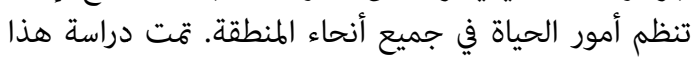
التغيير من خلال مثال مدينة استولاك "Stolac" (تنطق:

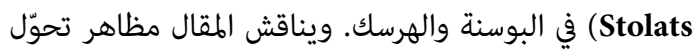
مستوطنات القرون الوسطى من قرية الهرسية صغيرة إلى إلى مدينة

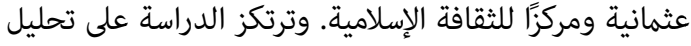

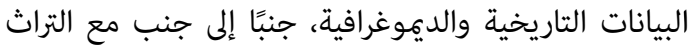

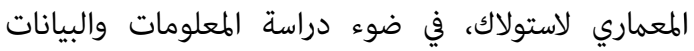

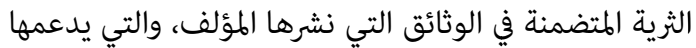
المعلومات الواردة في كتب الرحالة ونتائج العمل الميداني.

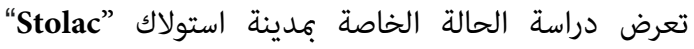
مناقشة النظريات ذات الصلة حول ظهور المدن عبر البلقان البران

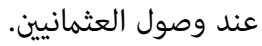

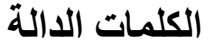
مدينة استولاك، البوسنة والهرسك، البلقان، البكان، المدينة العثمانية، مركزًا للثقافة الإسلامية، عمارة إسلامية.
\end{abstract}




\section{INTRODUCTION}

Since the end of the Roman and Early Byzantine period, say from 600 A.D. onward, the Balkans were largely a region without cities. Settlements with monumental public buildings, an urban structure and a population of craftsmen and merchants only survived on the coasts of the Mediterranean and the Black Sea. In the ByzantinoSlavic Bulgaria of the 10th to the 14th century a number of town-like settlements developed below unassailable mountaintop castles but they belong together with those found in medieval Finland, to the smallest in the whole of Europe. Serbia, Bosnia and Hercegovina were, generally speaking, lands without towns. Halfway through the 15 th century they still had a society and economy at the level of Western and Central Europe in 1150. This means lands studded with mountaintop castles of powerful feudal lords, large land-owning monasteries and a mass of peasants living in feudal servitude.

With the coming of the Ottoman Turks, especially after the Battle of Varna (1444), the Ottomans consolidated their hold. This picture begins to change rapidly as settlements with an urban structure, a population living from crafts and trade and a proper administration mushroomed all over the region. In this context it is worth remembering that the capital cities of Bosnia and Hercegovina, Sarajevo and Mostar, but also all the other major towns like Banja Luka, Travnik, Tuzla and Zenica along with scores of lesser known were founded by the Ottomans.

Several theories have been formulated to explain why towns arose everywhere across the Balkans with the coming of the Ottomans. The founding father of the study of the Ottoman population based on taxation records (tahrir defterleri) Ömer Lütli Barkan saw them as the product of imperial will and initiative, intentionally founded and financed, appearing ex nihilo. His main opponent, the Bulgarian scholar and former head of the Bulgarian Academy of Science Nikolaj Todorov saw a much greater degree of continuity between the medieval settlements and the Ottoman towns. Neither took into account that dozens of places, now big towns, had emerged spontaneously, out of the need for market centers to exchange the products of a fast growing population. This population growth was a direct result of the lasting peace the Ottomans had brought to the Balkans, the "Pax Ottomanica" that endured as long as the Pax Romana, albeit much less known.

In this contribution we shall focus on the development of one town in the Hercegovina, Stolac. It is one of the most romantic places of this stony and infertile, yet beautiful, land. We shall follow the development of Stolac from 1468 onward till 2008 and so add a mosaic stone to the complex history of urban development in South-Eastern Europe.

Today the little town of Stolac lies in the Croatian controlled part of the BosnianHercegovinan Federation, $35 \mathrm{~km}$ south of the Hercegovinan capital of Mostar.

- 185 - Stolac from a hamlet to an Ottoman town and Islamic cultural centre 
Together with Podgorica/Titograd in Montenegro it shares the reputation of being the hottest place of Yugoslavia. Stolac lies at an altitude of only $64 \mathrm{~m}$ above sea level but is surrounded by barren mountains rising to over a thousand meters. These mountains and the course of the little river Bregava (tributary of the Neretva) determine the outlay of the town. It has the shape of an irregular $-\mathrm{T}$, formed by the east-west aligned bend of the Bregava and joined by a narrow valley coming in from the south. In the $18^{\text {th }}$ and $19^{\text {th }}$ century Stolac produced, besides influential politicians, a number of well-known scholars and some of the most outstanding poets and writers of Ottoman Turkish literature. The greatest writer of $20^{\text {th }}$ century Bosnian literature, Muhammed Ali (Mak) Dizdar, is also a son of Stolac.

The town, which now has some 5,500 inhabitants, is an Ottoman creation and lies at the foot of the ruins of the small medieval mountaintop castle of Viduški Grad. (In the Slavic languages 'grad' means castle, as well as town). In the 15th and 16th centuries Stolac remained a village but in the course of the 17th century it developed into a town. The Ottoman tahrir defters allow us to follow its development from a hamlet to a town that, for its time and place, was big and important, even if by the standards of our time it was very, very small and still is. Since the early years of the $18^{\text {th }}$ century Stolac has been dominated by a mighty Ottoman castle, the largest of the Hercegovina.

\section{NAME}

The name Stolac (pronounced as 'Stolats') is thought to have derived from two massive chairs, or stol, cut in the living rock in the small wood near the Orthodox Church of Sts. Peter and Paul of the village Ošanići on a plateau overlooking the town. Here the medieval lords of the region (the Miloradovic clan) are thought to have dispensed justice.

\section{MEDIEVAL STOLAC}

Grad Vidoški owes its name to the small river Vidoštica, now called "Bregava." The Vidovo Polje (Plain) and Stolac are mentioned in 1436 and 1444. The castle of Stolac, known as Vidoši or Vidoška, was the centre of the župa (district) of Vidovo Polje. The castle is first mentioned in 1375. The Vidovo Polje and Stolac are mentioned together in 1436. Lamenta de foris mentions the Vidoški Grad on 18 February $1444 .{ }^{1}$ Stolac was situated on the trade route from Dubrovnik to the Balkan interior, or better, completely blocks this important road. Below the castle, on the narrow strip of flat land between the foot of the Castle Hill and the river Bregava, was a small suburb called Podstolac. A number of great medieval funeral monuments, the so-called "Bogomil Stones," strewn over the Vidovo Polje, still vividly remind us of the rustic expressiveness of the medieval culture of the area.

It should be stressed that medieval Stolac had been very small. Extensive archaeological research, carried out in the 1970s under Izet Rizvanbegović, made clear that the castle was restricted to a small triangular space. Almost all we see today 
is either Ottoman or belongs to the Austrian period (1878-1918). ${ }^{2}$ The suburb Podstolac cannot have been big either. It was situated in the part of town since old known as Podgrad Mahalle ("Below the castle"). In the imagination of some Croatian authors medieval Stolac is thought to have been a big settlement with a Catholic monastery in the lower town. When in 2002/3 excavations were carried out under the site of the destroyed Mosque of Sultan Selim I, in the present town centre, foundations of an older building were found. The Croat masters of the town immediately declared them to be the ruins of the Catholic monastery and wanted to have it reconstructed. ${ }^{3}$ In fact they had found the light a symbol of the resurrection of Christ, to fall through the apse window and strike remains of the original mosque of Sultan Selim, which in the 18th century was replaced by a much larger one. Mosques are oriented toward Mecca, which in the West Balkans is south-east. Christian churches point due east, to enable the early morning the altar. Thus there is no church in today's centre of Stolac, the only place where there would have been sufficient flat land to build a town centre. We should remember in this context that Serbia, Bosnia and Hercegovina were lands without cities in the time before 1450. Balkan-Slavic Christian society was by the mid-15th century still at the level of Western- and Central Europe in 1150. The region was studded with the mountaintop castles of continuously warring feudal lords, and rich land-owning monasteries with splendid churches, but no towns. A brief comparison between some of the larger towns in Western Europe with the largest in the Byzantino-Slavic territories is sufficient to demonstrate this point.

\section{EARLY OTTOMAN STOLAC.}

Stolac must have been taken by the Ottomans in 1466, together with most of the Hercegovina, and not in 1471 (death of Herceg Stjepan), as was thought previously.

The 1468/69 tahrir M. Cevdet Yazmaları O.76 in the Atatürk Kitaplığı, Istanbul, is the oldest source giving statistical information on the inhabitants of the place. ${ }^{4}$ It mentions "İstolçe" twice. First as an empty plot of land with two vineyards on it and a watermill, giving a total yearly revenue of 500 akçe. ${ }^{5}$ It was part of the timar of "Radosav, son of Stepka," one of many local Christian military men in Ottoman service and an example of the careful Ottoman policy of integrating new territories into their system. ${ }^{6}$ The second mention is "karye İstolçe" (village of Stolac), having eleven houses of Christian inhabitants and being part of the timar of Ivaniš, another Christian cavalry men in Ottoman service. The small castle must have been dismantled by the Ottomans. It is not mentioned in the census and neither is a garrison.

In the eleven years between the first and the second registration of the Herce-govina, T.D. No 5 from 1477, the hamlet of Stolac doubled in size, from 9 to 18 households, still all Christians. It still had the status of a village (karye) and was to keep this for

- 187 - Stolac from a hamlet to an Ottoman town and Islamic cultural centre 
the decades to come. The early history of Ottoman Stolac has been studied by Spaho and by Kupuzović. ${ }^{7}$ They used the two registers mentioned above. Spaho also used the register from 1585, but between 1477 and 1585 there are at least two more registers. One is Kepeci 697, from 904 (1498/99), and the other T.D. 167, from 925 (1519).

The 1498-99 register allows us to see that in the last two decades of the 15 th century Islam began to spread among the villages of southern Hercegovina. This was a slow and creeping process which can be followed with help of two registers, not used previously. On folio 14a of the 1499 register we find: "Village of Istolac belonging to Viduška, Zi'amet-i Yunus Kilari, Muslims: 8 households, non-Muslims: 40 households." Stolac had thus seen a remarkable population growth. In 22 years it more than doubled in size and no longer belonged to a Christian sipahi but to an Ottoman servant, the kitchen master Yunus. What is more remarkable, however, is the fact that now $17 \%$ of the population was Muslim. This marked the beginning of an almost complete Islamization of the town in the course of the 16th century.

In the 20 years until 1519 the trend went on. The village had grown further but not as fast as before. The Muslims more than doubled, to 18 households, bringing their share to $31 \%$, whereas the Christians started to decline in number. This was the point where the Ottoman State intervened. In the same year, by order of Sultan Selim I (1512-1520) a mosque was built in Stolac. The same policy can be detected in other places in Bosnia and Hercegovina where villages started spontaneously to accept Islam and where the state than helped by erecting houses of prayer. A good example is the village of Knežina, in East Bosnia, where a small but stately domed mosque in Classical Ottoman style survived until 1992 (when the Serbs blew it up), dating from the time this former Christian village started to develop into a small Muslim town. Its builder was the same Sultan Selim I. $^{8}$ In this cases we see a direct and deliberate intervention by the State in line with Barkan's theory, although on a much more modest scale than he argued.

In the 66 years between 1519 and 1585 Stolac doubled once more in size but this time the Christians had greatly gone down in number. The village had now 107 households, or about 490 inhabitants, of whom 74\% were now Muslim. Stolac was now one of the largest settlements of the district and clearly on the way to becoming a small market town. ${ }^{9)}$ It is worth noting that the register very clearly shows that the growing number of Muslims was not due to immigration of Muslims from other parts of Bosnia or the Balkans at large but to the spontaneous conversion of the local population. In 1585 register shows that $25 \%$ of the Muslims had no Muslim fathers but were new converts. In the generation before them the percentage must have been roughly the same. Those who wrote about Stolac previously, especially Hivzija Hasandedić, failed to draw on the rich information from the Ottoman registers and primarily thought of immigrants from elsewhere.

An indication of the slow transformation of Stolac into a minor town is given in a berat of 16.2.1226 (12. march 1811) preserved in the Gazi Husrev Bey Library in 
Sarajevo. It deals with the foundations of Silihdar Hüseyin Pasha, who played an active role in the last decades of the 16th and first of the 17th century. In his native Stolac he had built a hamam, a khan, and a müsafirhâne (guesthouse), where travellers and guests were lodged and fed free of charge. Buildings of this kind are typically urban and show that the village was taking an urban character. Here it was not the central State but one of its middle ranking officials that played the other part in transforming the village into a town. Thus elements of both Barkan's and Todorov's theories can be seen at work in Stolac. Silihdar Hüseyin Pasha also made provisions for extra salary for the muallim (teacher) of the school (mektep) of the Mosque of Sultan Selim. His descendants, the later so important Šarić family, were Mütevelli, or administrator of the vakf. ${ }^{10)}$

In the Ottoman Archives in Istanbul there must be a number of registers of the poll tax on non-Muslims (Cizye Defters) in which the decline in numbers of Christian households in the 17th century could be traced. Unfortunately those for the Hercegovina have not (yet) been localised.

What we have for the development of Stolac in the 17th and 18th centuries, and in fact for all towns and villages of the Hercegovina, are the reports of spies and travellers.

\section{The "Relatione" of Athanasio GEORGICEO, 1626.}

In the year 1626 an agent of the Vatican, Athanasio Georgiceo, travelled through Bosnia and Hercegovina and left a report, written in Italian, containing data on household numbers of many towns, as well as information about the military strength of those places, numbers of soldiers in them etc. Sometimes he also gives some information on the mosques he saw. Thus, reporting on Stolac, he writes: (p.137)

"Stolac, too, is a fortified town, situated on a mountain, at the foot of which is a plain with many houses that altogether, including the castle, which is ruined and uninhabited, can mobilise 150 men able to bear arms. It is situated five days from (the chief Venetian base of) Spalato (Split.) $)^{\prime 11}$

If we apply the established demographic ratio to the aforementioned 150 men able to bear arms (roughly between 13 and 60 years of age) by multiplying this group 3.5 times, we arrive at the number of inhabitants totalling 530 inhabitants. In 1585 this had been some 470 inhabitants. Taking account of the very slow growth of the $17^{\text {th }}$ century, the 530 figure for 1626 does not look unlikely. In the 39 years between Georgiceo's report and the visit of the famous Ottoman traveller Evliya Çelebi $(1664 / 65)$ the population grew to about 1,200 souls, assuming Evliya's numbers are correct.

- 189 - Stolac from a hamlet to an Ottoman town and Islamic cultural centre 


\section{Evliya Çelebi's Seyahatnâme, ${ }^{12}$}

When Evliya travelled in the Hercegovina it was in the years of the OttomanVenetian war over Crete, 1645-1669, his account contains much more information on Stolac than Georgiceo's report. It becomes clear that the place had developed further and had become a small town with a fully developed Islamic life. Evliya wrote:

"Following this river (the Dol Deresi, now: Bregava) we arrived in three hours in the small town (kasaba) of Ustulçe. It is a Voyvodelik and the seat of a Kadı in the Sandjak of Hersek. All around it are high rocks. It is a nice little kasaba, having mosques, three mesdjids, a small hamam, a khan, 20 shops and about 280 stone-built houses covered with slates (kayagan in Tr.) all placed in well-watered gardens and vineyards. Out of fear for the enemy all the houses are built of stone and some have square towers with heavy ironclad gates. In these districts roof tiles (keremid) are rare. All the houses look to the west. Being on the Dol Deresi (Bregava), the ten watermills of this place are all turned by the water of this river. In these districts all rivers run in a western direction and flow in the river Neretva." ${ }^{13 a}$

It is interesting to see that Evliya does not say one word about a castle in Stolac. It must have become an overgrown ruin, difficult to see from the town far below it. With 280 houses Stolac would now have between 1,200 and 1,300 inhabitants, the expansion being largely due to new settlers from the surrounding villages.

\section{Stolac and the Herzegovina during the Cretan War (1645 - 1669).}

The effects of the Cretan war were not only deeply felt on Crete but also in Dalmatia and the western parts of the Hercegovina, even if much less sharply. The Hercegovina had seen two centuries of peace and recovery, the"Pax Otto-manica." Now bands of robbers, hayduks, and the much-feared Uskoks plun-dered and devastated the land, being, or pretending to be, in Venetian service. In his travel account Evliya gives a vivid impression of the effects of the war. Coming from the high mountain valley of Nevesinje he noted the village of Zobdol, which had been a small town, was now ruined because of the continuous attacks by raiders in Venetian service. From Zobdol, Evliya, in the company of fifty soldiers armed with rifles, crossed the Trusina Mountains in six hours "with a thousand difficulties"13b and descended to:

"The menzil village of Dabar. It is a Muslim village. Because of fear of the unbelievers, the inhabitants sleep every night in the mountains. From there, we went straight down the plain of Dabra heading west and arrived after four hours in the kasaba of Dol (Predolje)."

"Predolje had been a small town built from stone and surrounded by gardens and vineyards, housing a beautiful mosque, two mescids, one tekke, one small hamam, one han, and 15 shops. ${ }^{14}$ But shortly before our arrival there was an enormous fight with the unbelieving Uskoks and many Muslims were taken 
prisoner and the entire population fled up into the mountains along difficult paths. In the gardens and vineyards were, through God's grace, delicious juicy fruits laying on the ground everywhere. By God's judgement it (Predolje) is a paradise-like village looking like the (mythical) garden of Irem. However, this poor one saw that in this kasaba there was not a single son of men, and because all had fled we also fled and went from here, going in a western direction straight through the valley of the little river Dol (now called: Bregava). On the left side of the rivulet the entire earth - along a three-hour walk -- was covered with fine gardens, but their owners had all taken themselves to safety and were unable to harvest the fruits."

After extolling the superb quality of the musk-smelling juicy grapes of Predolje and the delicious wine that could be made from them, Evliya and his party arrived in Stolac. One day before their arrival in Stolac, a force of "5,000 men" had attacked the town, taken many prisoners, carried off much booty and set fire to the houses. Some fires were still burning when Evliya and his group arrived. When the town's Muslims who had managed to lock themselves in the towers saw that the newcomers were also Muslims they came out and offered them a tower in which to stay. A short time later, in a lightning attack by an Ottoman force under Suhrâb Mehmed Pasha, the Venetian forces were beaten and some 300 prisoners taken from Stolac were liberated. ${ }^{15}$ The numbers given by Evliya for Zobdol, Dabra, Predolje, and Stolac look perfectly acceptable. Although his story is adorned with literary clichés it does give us the flavour of that violent time.

From this description it can safely be concluded that Stolac had now made the jump from village to town. It had been a process stretching out over almost two centuries and contains elements of both theories on the emergence of Ottoman towns, combined with a large dose of spontaneous growth.

During the long war against the Christian coalition, 1683-1699, the Hercegovina was to suffer again. We learn from a chronicle in private possession in Mostar, and used by Hamdija Kreševljaković, how in August 1687 a force of "5,800 men under Nikola Novković" was beaten back by the Muslims of the Stolac area. In 1106 (1694/95 another Venetian force was beaten in a battle near Radnica, whereby the Commander, his banners and his artillery were captured. On none of these occasions is a castle or stronghold in Stolac mentioned. ${ }^{16}$

After the Treaty of Karlowitz of 1699 finally ended the conflict and settled the borders it was decided to better fortify the southern part of the Hercegovina. In the years after 1699 the ruins of the medieval castle of Stolac were rebuilt and greatly enlarged. At the same time a completely new town was built on the site of the hamlet of Trebinje. Important parts of both new fortifications remain until today. In the

- 191 - Stolac from a hamlet to an Ottoman town and Islamic cultural centre 
following decades a number of new buildings needed for the Islamic way of life were erected in Stolac.

\section{THE HISTORICAL MOSQUES OF STOLAC.}

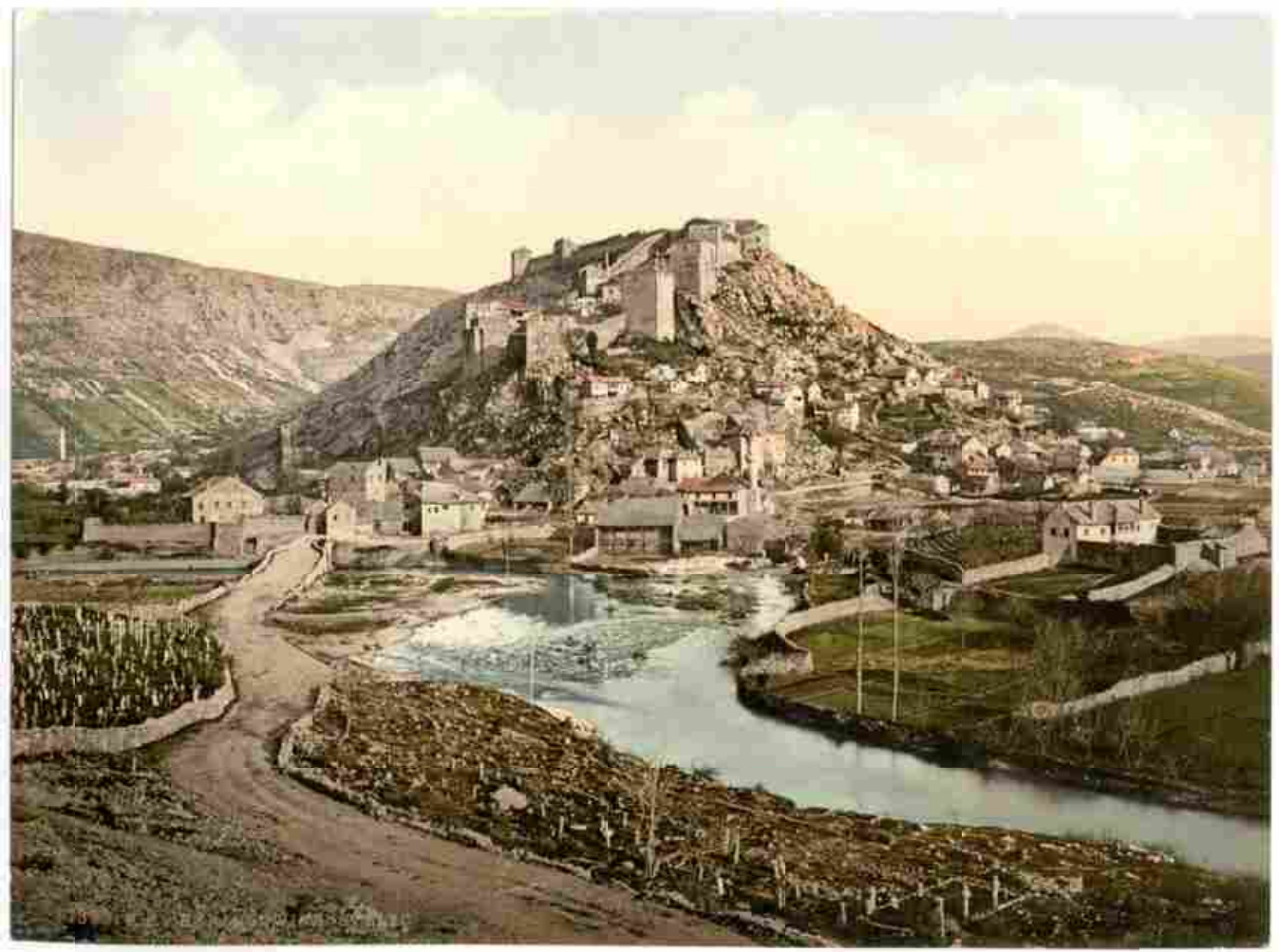

Stolac (Bosnia, Austro-Hungary Empire) in 1890-1900; Showing the fort and the town, where two Ottoman mosques appear.

(Source: Photochrom Print Collection - Library of Congress Catalog: http://lccn.loc.gov/2002710701 Print no. "17399".; Forms part of: Views of the Austro-Hungarian Empire in the Photochrom print collection.; On print: Herzegowina. Stglac[?].; Title from the Detroit Publishing Co., Catalogue Jforeign section, Detroit, Mich.: Detroit Publishing Company, 1905. [Access date 7.9.2020]

\section{1) Careva Džamija}

The first of the historic mosques of Stolac is the "Careva Džamija," the Mosque of the Tsar, originally built in 1519 by order of Sultan Selim I, as related above. It is a rectangle of $18.10 \times 10.85 \mathrm{~m}$ covered with a slated wooden roof and located in a spacious walled garden. In this garden are the graves of many famous inhabitants of Stolac, members of the families of Ljubović, Šarić and Rizvanbegović. Above the entrance of the mosque was a long Ottoman inscription relating the overall reconstruction and enlargement of the building to the year 1203 (1788-89). The text is the work of the once famous poet-judge Ibrahim Vehbi Zekić, Kadı of Stolac. It was published by Mehmed Mujezinović. ${ }^{17}$ The present mosque can easily accommodate 200 worshippers. For the 15 or 20 adult Muslims of Stolac in 1519 this would, of course, have been much too big. The present mosque must thus be a different and larger building than the original. Here the inscription by Vehbi gives us some hints to understand the history. 


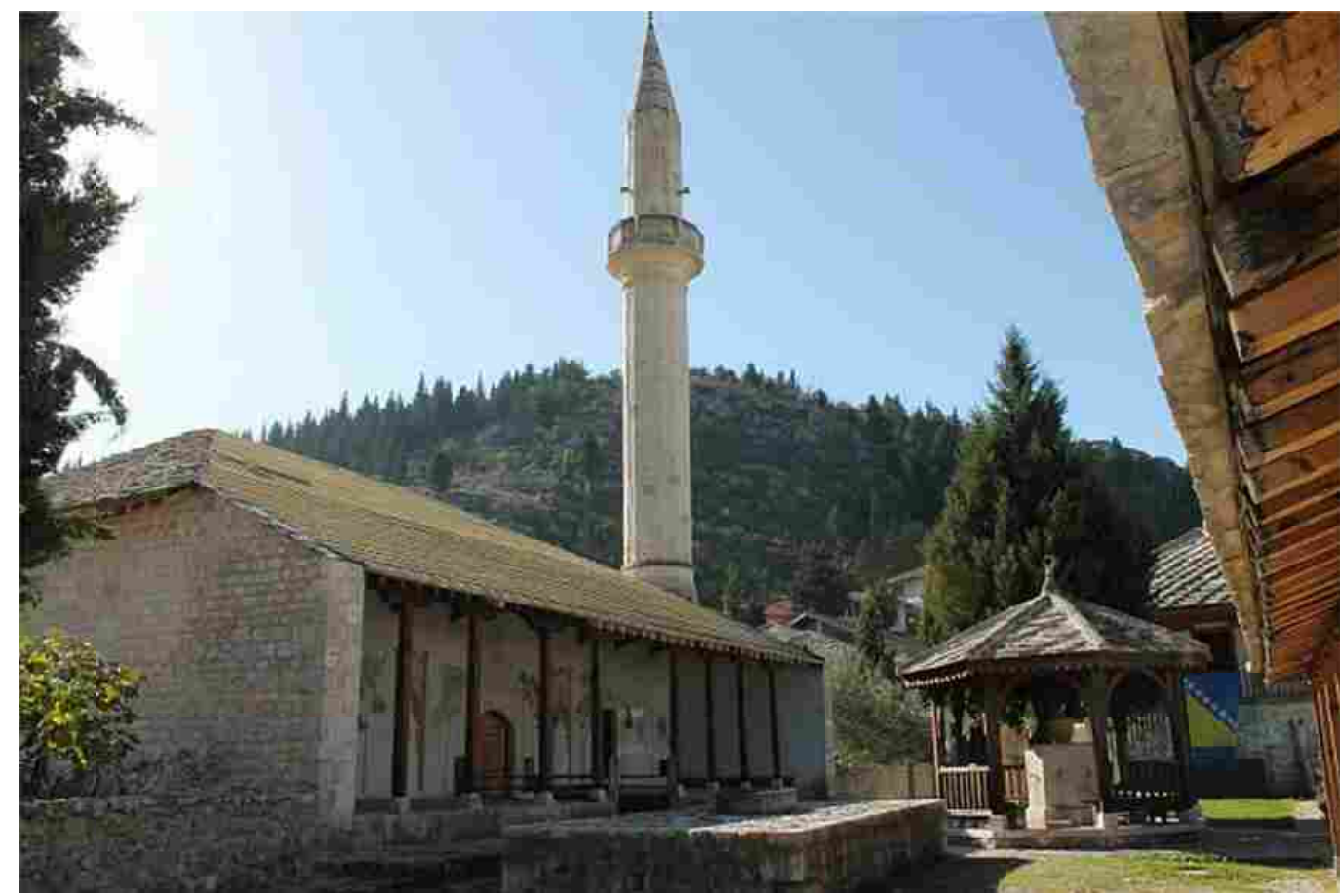

Careva Džamija

(Source: http://www.tourguidestolac.com/sultan-selimova-ili-careva-dzamija/ [Access date 7.10.2020])

The inscription mentions the original founder of the mosque explicitly as: "Cenâb-1 Hazret Sultân Selim, feth-Misriñ" (His Majesty Sultan Selim, Conqueror of Egypt). It continues with the statement that in the course of time the building needed repair (mürûr-1 ezmâne ile oldı̆̆ 1 muhtac-1 ta'mir). The third distych and the chronogram explicitly mention that the building was rebuilt entirely in a new form (zehi ta'mir-i cami'-i mu'allah buldi nev uslub). The date written in numbers underneath the inscription gives us H. 1203. The chronogram itself is dated 1204, indicating that the building was finished earlier than planned. The poet of the text is the well-known poet and Kadı Vehbi from Stolac. The years over which the rebuilding work took place were from 1788 to 1790 .

The foundations of the, much smaller, first mosque were found back in 2001/2002, and created a local sensation, as related above.

\section{2) The Mosque of Ali Pasha Rizvanbegović.}

A new mosque was built in 1145 (1732/33) by Hadji Salih Bure. It was erected in the Podgrad Mahalle in the western part of the town. In 1227 (1812-13) this building was replaced by a new mosque by Ali Agha, the later so famous Vezier of all the Hercegovina, Ali Pasha Rizvanbegović (1783 -1851). In 1888/89 the mosque was restored by his descendent Mehmed Ali Pasha Rizvanbegović. It is built on the tip of land where two branches of the Bregava unite, partly over the water and resting on a high substructure where three shops are accommodated behind an elegant porch with three arches. Two inscriptions in Ottoman Turkish relate the story. The inscription of 1812 is another work of Ibrahim Vehbi Zekić, Kadi of Stolac. ${ }^{18}$

- 193 - Stolac from a hamlet to an Ottoman town and Islamic cultural centre 


\section{(3) The Mosque of Smail Kaptan Šarić}

According to Kreševljaković ${ }^{19}$ Smail Ağa Šarić was Kapetan of Stolac between 1731 and 1761. He donated a plot of land in the bazaar of Stolac on which twenty shops had to be built as vakf property to provide revenue for the upkeep of the mosque he had built in Stolac in the year 1154 (A.D.1741) He also donated 83,000 akçe as vakf for the same mosque. The vakfiye of Smail Kaptan is preserved in Sarajevo, in the archives of the Directorate of the Vakfs. It is undated.

\section{4) Mosque of Hadži Ali Salihović, in the Hamam Mahalle, 1730.}

The third mosque in order of time is that of Hadži Salihoğlu son of Hasan. This building is situated on the bank of the Bregowa, $50 \mathrm{~m}$. from the bridge over the river. This part of the town is called: Hamam Mahallesi after the hamam built at the end of the $16^{\text {th }}$ by Silahdar Husein Pasha. The mosque is built of carefully cut blocks of stone. The rectangular building is covered by a pyramid-shaped wooden roof. About the patron very little is known. In the time the mosque was built Hadži Ali was serving as Commander in the Ottoman army stationed in Cairo. The mosque was built just before 14 February 1736, the date in which the Vakufnâme (foundation charter) was written. A copy of this document can be seen in the Acta Turcorum in the Gazi Husrev Bey Library in Sarajevo under the No 3-140. ${ }^{20}$

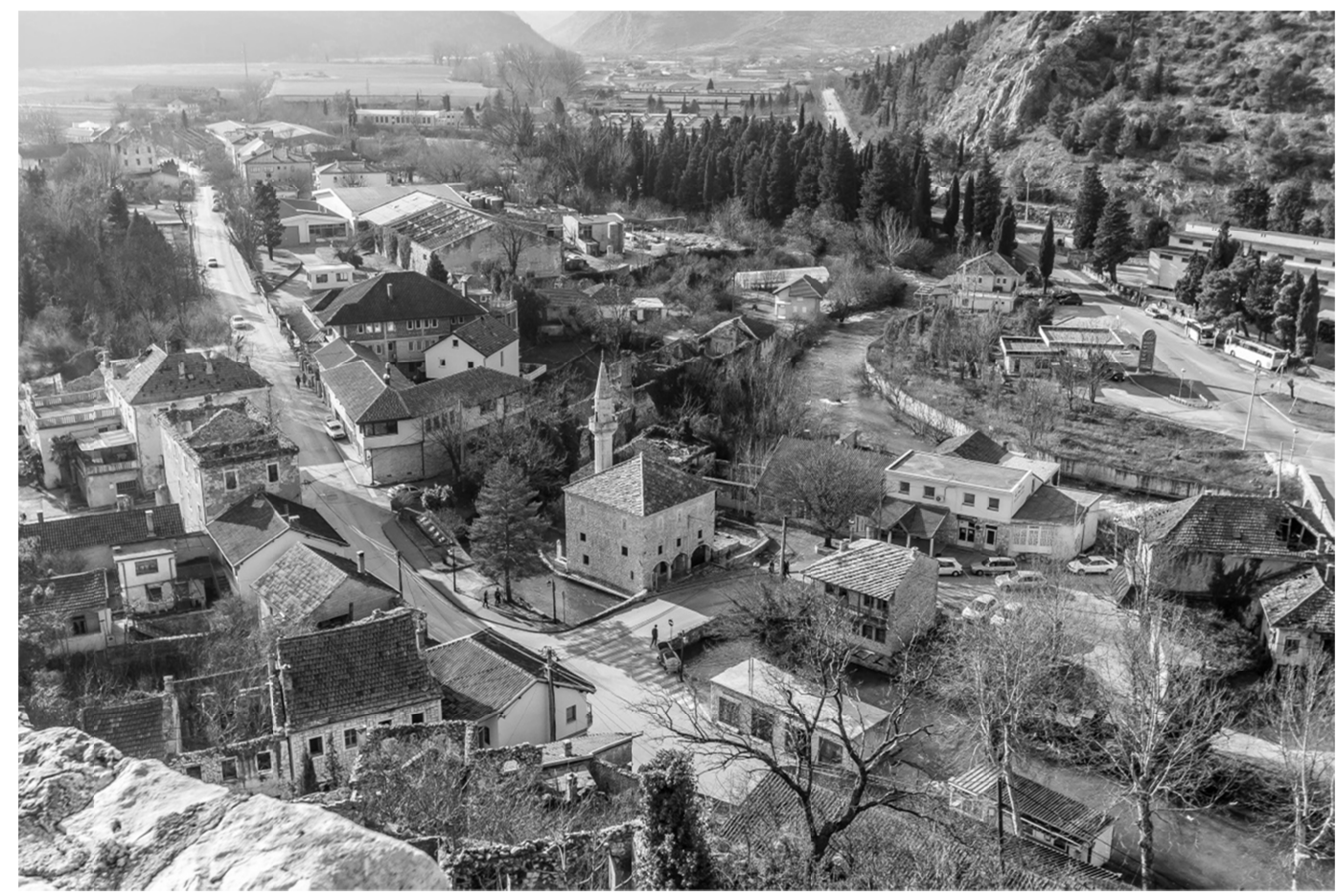

Mosque of Hadži Ali Salihović (1730), in the Hamam Mahalle.

Source: After, https://www.flickr.com/photos/secretdalmatia/32052991233/in/photolist-QQpXzT-a8ruBm-o1EGsM-nJb8EZnJb7eT-o1EG2B-nYCef7-nYCdiY-nYCcUS-nJb6aD-o1EJWe-nJb8gT-o1nrRn-o1ntsP-2iZVfMF-nJbkES-z5xUek-5tEndwRQQAuY-YnnrwR-nJbhVo-9yE6rb-9yE7b1-a8rw2d-25WNSyY-RQQB1C-QMVDbh-JELRNH-a8rxxJ-5pFJDu-S1LZT3S1LRK9-2iZXXHN-QQpWN2-2iZZxgy-a8rvCh-XG7syo-RQR8EU-RuKzm3-S1NopU-S1NmYN-S5qWsF-RTvvWZ251RrSN-RQR5Vq-QMWJt9-RTvcST-S5qB7g-QQpXTD-RuJVS5 [Access date 7.12.2020] 
In 1760 there was a catastrophic explosion when the castle's gunpowder store was struck by lightning. The little known Bosnian poet, Molla Ibrahim Lubini (from Ljubinje) wrote in Ottoman Turkish a tarih of 14 beyts on the completion of the building of Stolac Castle and gives the date of its completion as $1176(1762 / 63)$.

The well-known Bosnian poet Mehmed Mejli also wrote a poem about the same occurrence. The name of the poem is "Saraylî Šurânî Efendi guftesi berâyı Stolçe", which has seven beyts.

The otherwise little-known poet Torun Efendi wrote a tarih of six beyts about the same event.

Copies of these three poems are, or at least were, in a Mecmu'a kept in Mostar, and described in detail by Hazim Šabanović in his "Knjževnost." 21

The same period was dominated by the rule of Ali Pasha Rizvan Begović (17831851), Kaptan of Stolac, and between 1833-1851 Gouvernor (Vezir) of all of Hercegovina. In 1813-14 (1229) he succeeded his father as Kaptan of Stolac. In the same year, during the infighting between the various local potentates, he was wounded at the siege of Počitelj and remained cripple for the rest of his life. In February 1832 Stolac was besieged by the troops of the rebellious Hüseyin Bey Gradaščević but the town held out.

Table 1. Demographic Development of Stolac through the Ages (n.d. = No Data)

\begin{tabular}{|c|c|c|c|c|}
\hline Year & Hâne Muslim & Hâne Christ & Total Hâne & Percent Muslim \\
\hline 1468 & 0 & 9 & 9 & 0 \\
\hline 1477 & 0 & 18 & 18 & 0 \\
\hline 1499 & 8 & 40 & 48 & 17 \\
\hline 1519 & 18 & 39 & 57 & 31 \\
\hline 1585 & 79 & 28 & 107 & 74 \\
\hline 1664 & 280 & n.d. & $(280)$ & 100\% Muslims? \\
\hline 1867 & n.d. & 820 & 3500 (Christ. Inhab.) & n.d. \\
\hline 1910 & 423 & 208 & 631 (hâne) & 67\% Muslim \\
\hline 1948 & n.d. & n.d. & 2.320 Total inhabitants & n.d. \\
\hline 1953 & n.d. & n.d. & 2489 Total inhabitants & n.d. \\
\hline 1961 & n.d. & n.d. & 3061 Total inhabitants & n.d. \\
\hline 1971 & n.d. & n.d. & 3872 Total inhabitants & n.d. \\
\hline 1981 & 3146 Muslim inhab. & 1816 Christ. Inhab. & 4962 Total inhabitants & 64\% Muslim \\
\hline 1991 & 3426 Muslim inhab. & 2104 Christ. Inhab. & 5530 Total inhabitants & 62\% Muslim \\
\hline
\end{tabular}

In the first half of the $19^{\text {th }}$ century Stolac gave birth to one of the greatest poets of the Late-Classical Ottoman poetry: Hersekli Arif Hikmet. ${ }^{22}$ 
After World War I, 1918, the rule of the Habsburgs ended. Bosnia and Herce-govina were incorporated in the newly formed state: Yugoslavia. Before WW II the percentage of Muslims must have been around three quarters of the total population. In 1910, under Austrian rule, it was even more. Stolac was held to be one of the "most beautiful and romantic towns in Bosnia-Herzegovina."23 In 1948, immediately after the cruelty and destruction of WW II, Stolac had 2,320 inhabitants in total. Over the further development see the below the table which gives a total overview over the centuries:

It is remarkable that between 1948 and 1991 the population of the villages of the district of Stolac hardly grew. It remained stagnant at around 18,500 souls, peaking at 19,230 in 1971 and slightly declining till 1991 (to 18,681). Of these inhabitants, the Muslims numbered 8,100, the Croats 6,200 and the Serbs 3,900. The town of Stolac, with its new and better job opportunities, had evidently attracted people from outside. In the 43 years after 1948 the town doubled in size.

\section{Destruction}

In the summer of 1993 the Croatian army (HVO) took Stolac in a surprize attack and tried to make an ethnically clean Croat Catholic town of it, although the Croats counted for only $12 \%$ of the town's population, as we have seen. The Muslims were deported and put into concentration camps under horrendous conditions. The Serbs fled or were also chased out. The HVO then blew up three of the four existing mosques and bulldozed their ruins away. The three destroyed ones were all situated in the centre of town. The fourth one, the Sarica Mosque, was in the more outlying Kumluk Mahalle to the south. It was set on fire but survived largely intact, be it without a roof. Five years after the Dayton Treaty, in the year 2000, the Kumluk Mahalle, formerly an entirely Muslim quarter, was no more than a horrifying pile of concrete and bricks from blown-up houses.

\section{Resurrection}

In 2002/3 almost the entire Muslim community of Stolac, and of the villages in its surrounding district, numbering altogether 14,000 people, returned to their native homes. Those Muslims in Stolac succeeded in raising the money to reconstruct the whole of the largest and most important mosque of the town, that of Sultan Selim I from 1519. Its inscriptions, preserved in the great work of Mehmed Mujezinović ${ }^{24}$ were re-made in their original form.

In 2005 the Sarica Mosque was also restored, carefully and with great taste, and again serves as mosque. In the summer of 2007 rebuilding work was underway on the Mosque of Ali Pasha Rizvanbegović (Podgradska), again in the same careful manner, and was approaching completion in June 2008. As for Stolac's fourth mosque, the Mosque of Hadži Ali Salihović, most of the walls had been re-erected by 2006. In June 2008 we saw that it had been finished and was again in operation. One of the 
major konaks (mansion) of the Begova-complex of the Rizvanbegovic family had been restored by 2006. The other konaks were still in ruined and burnt-out shape. In 2007 the restoration of the great mansion of Ismail Ağa Šarić near the Careva Džamija, which dates back to 1745, was almost completed. By 2005 the entire Kumluk Mahalle had been rebuilt. In the summer of 2008 there was only a bit more needed to be done. Once completed, Stolac will have undergone a resurrection, being transformed from the most destroyed town of the Hercegovina into the best rebuilt. The deep scars in the psyche of the inhabitants will need much longer to heal. 


\section{NOTES}

1) See: Marko Vego, Naselja Bosanske srednjevjekovne država,: Sarajevo 1957, p. 124/25). Marko Vego, in this excellent overview notes that: "Stolac is first mentioned in 1375 under the name Vidoški Grad. Below the castle was an open suburb called Podstolac. Grad Vidoški owes its name from the smal river Vidoštica, nu "Bregava." The Vidovo Pole and Stolac are again mentioned in 1436 in 1444; See also: L. Thallóczy, Studien, p. 361, and M.J. Dinić, "Zemlje hercega Sv. Save," in: Glas Srpska Kraljevska Akademija, No 182, p. 182-184.

2) Izet Rizvanbegović, "The results of former archaeological researches at the medieval fortress Vidoška Tvrdjava at Stolac." in: Balcanoslavica VIII, Beograd 1979, pp. 77 - 92.

3) The story of the "church ruin" underneath the Mosque of Sultan Selim has to the best of my knowledge not been written down. It was communicated to us by the local Muslims during our visits to Stolac in 2003, 2004, and independently by the Director of the Institute for the Protection of Historical Monuments, Prof. Ir. Ferhad Mollabegović. It should be added that this is a favourite topos in Balkan Christian folklore, which imagines medieval churches beneath almost every mosque, even those of cities founded by the Ottomans as pure Muslim centres. A case in point is the town of Razgrad in North Eastern Bulgaria, where under the floor of the monumental Mosque of Ibrahim Pasha from 1616 some ruins where found. The Bulgarian Press and Television immediately publicised the discovery, stating that the cathedral of the (imagined) medieval town of H'razgrad had been found. By digging further it was found that the ruins were not orientated to the east and had a mihrab pointing to Mecca. It was the smaller forerunner of 1525/30, enlarged and replaced in 1616. For this part of the story press and television had no interest. For details see: Machiel Kiel, "H'razgrad - Hezargrad - Razgrad,: The vicissitudes of a Turkish town in Bulgaria (Historical, Demographical Economic and Art Historical Notes)," in: Turcica XXI-XXIII, Paris 1991 (Mêlanges offerts â Irêne Mêlikoff) pp.495-563.

4) Now entirely published by Ahmed S. Aličić, Sumarni popis sandžaka Bosna iz 1468/69 godine, Mostar 2008 (Islamski Kulturni Centar), p. 61 and 158.

5) In original wording:"zemin-i İstolçe, hali, bağ 2, âsyâb nisf, hasil 500."

6) The dominance of Christian cavalrymen in the Ottoman army (sipahi) in the first decades of the rule was common throughout the Balkans. In the Hercegovina this dominance was more marked than elsewhere. In 1468/69 the Nahiye of Trebinje, just south of Stolac, had 26 villages with 22 sipahis residing in them. Only one of them was a Muslim by birth. The two other Muslim sipahis were recent converts ("nev muslim"), all the others (87\%) were Christian. In the important district of Braničevo in Northern Serbia $80 \%$ of the entire "Ottoman" military forces was Christian. For this see: Branislav Djurdjev, "Hrisčani-Spahije u Severnoj Srbiji," in: Godišnjak Istorskog Društva B. i H, IV, Sarajevo 1952, pp, 164-170.

7) For studies on the early history of Stolac see: Fehim Spaho, "Nekoliko novih podataka o Stocu iz XV i XVI stoljeća," in: Prilozi Or. Fil. 37, 1987, p. 197-201. Spaho did not use the entry about Stolac on p. 61 of the 1468 register.

8) For Knežina see M. Kiel, "KNEŽINA. The Rise and Fall of a Muslim Borough in Central Bosnia" in: Baha Tanman (ed.) Nurhan Atasoy’ya Armağan. İstanbul (Lale Yayıncılık) 2014, p. 259-268.

9) Ankara, T.K.G.M. Register No 483. For an extract of this register, giving the vital household numbers, see: Ahmed Aličić, "Privredna i konfesionalna strukture stanovništva u Hercegovini krajem XVI stoljuća," in: Prilozi Orijentalnu Filologiju, No 40, Sarajevo 1990.

10) The text of the berat of 1811 is preserved in the Sicill Vakufnâme, vol. 1, No 89, p. 296. It refers to a much older document, the foundation charter of Hüseyin Pasha, which did not come down to us.

11) The original is Codex 218 in the Archivio di Propaganda Fide, from p. 480 onward. The entire text was published by Fra M.N. Batinić under the misleading title: "Njekoliko priloga kbosanskoj crkvenoj poviesti," in: Starine Jugoslovenska Akademija Znanosti i umjetnosti, XVII, Zagreb 1885, pp. 77 - 150. 
12) Seyahatnâme vol. VI, p. 441/422. Y. Dağl1 - Seyit Ali Kahraman, VI, Istanbul 2001, p. 261.

13) The small hamam mentioned by Evliya still stands. For details see Hamdija Kreševljaković's nice monograph: Banje u Bosne i Hercegovine, Sarajevo 1956, p. 74.

13b) This is not one of the usual exaggerating of Evliya. In April 2008 writer of these lines crossed over the mentioned pass with the greatest thinkable difficulty.

14) Predolje was totally destroyed during the great war of 1683-1699 and never recovered. In our time it is a hamlet of 10 houses (autopsie). Between World War I and World War II the local historian Hasandedić was still able to inspect the remains of a mosque in Predolje, with parts of it still standing in the area called "Meydan." In 1936 the remaining walls and the minaret of the mosque were taken down and their materials recycled. Hasandedić also saw the foundations of three other buildings, the mektep, medrese and tekke, all mentioned by Evliya in 1664. H. Hasandedić, Muslimanska Baština u Istočnoj Hercegovini, Sarajevo 1990, p. 88.

15) Suhrab Mehmed Pasha is mentioned in the Ottoman "Who's Who" Sicill-i Osmani III, p.115. In the time Evliya visited Stolac he must have been Sandjak-Bey of the Hercegovina. He became Mirahor (Master of the Imperial Stables) in 1655; in Şevval 1067/1657, Beylerbey of Sivas, and Beylerbey of the Eyalet Kanisza in Hungary, where Evliya (Putopis, I, 269) saw him. In the summer of 1663 he became Sandjak-Bey of the Hercegovina. He must have remained there until Cemazi I in 1076 (9 November 1665), when he was promoted to Governor-General of Bosnia (Sicill III, p. 115). Afterwards he became commander of the just conquered fortress town of Ujvar (Neuhäusel, Novy Zamky in Slovakia, where he died in June 1669. He was a powerful and sincere man (Sicill III: "1079'de Uyvar Valisi olarak 1080 Muharremında vefat etmişdir, muktedir ve sadık idi")

16) Hamdija Kreševljaković, Kapetanije u Bosni i Hercegovini, Sarajevo (2 ed., 1980) p. 225.

17) Mehmed Mujezinović, Islamska Epigrafika Bosne i Hercegovine, III, Sarajevo 1982, pp. 365-66. For Vehbi see: Rusmir Mahmud-Cehajić, "Ibrahim Vehbi, kadija, pjesnik i epigrafičar," in: Anali Gazi Husrev-begove Biblioteke, knj. IV, Sarajevo 1976, pp. 77-94.

18) Both inscriptions are published by Mujezinović, Epigrafika III, p. 370-3.

19) Kreševljaković, Kapetanije u Bosni i Hercegovini, p. 227.

20) Hasandedić, Muslimanska Baština u Istočnoj Hercegovini, p. 88.

21) Hazim Šabanović, “Knjževnost,” pp. 496-499.

22) Hersekli Arif Hikmet 1839 - 1903) was one of the greatest mystical poets of late Ottoman literature. His collected works were published by his longstanding friend and historian of literature Ibn ul-Emin Mahmud Kemal (İnal) as: "Hersekli Arif Hikmet Bey, Divan," Istanbul 1334/1913. See also: Türk Dili ve Edebiyatı Ansiklopedisi, IV, İstanbul (Dergâh Yayınları) 1980, pp. 208-209.

23) Kolind, "Non-Ethnic Condemnation in Post-War Stolac ..., ," pp. 121-134.

24) Mujezinović, Epigrafika III, 366.

- 199 - Stolac from a hamlet to an Ottoman town and Islamic cultural centre 


\section{REFERENCES}

1. Alexandre Popović, "Ridwân Begović Ali Pasha," in: E.I. 2, VII (1995) pp. 519-521.

2. Azra Gadžo-Kasumović, "Stolac u osmansko periodu," in: Hercegovina, Časopis za kulturno i istorijsko naslijedje, 13-14, Mostar 2001, pp. 81-99.

3. Carl Patsch, Aus Herzegovinas letzter Feudalzeit, Vienna 1922.

4. E.H. Ayverdi, Avrupa'da Osmanlı Mimârî Eserleri, Yugoslavya, II. Cild, 3. Kitab, Istanbul 1981.

5. Evliya Çelebi, Seyahatnâme, VI, (Ikdam ed.).

6. Fahrudin Rizvanbegović, Begovina Stolac, Sarajevo (Ministery of Education, Science and Culture), Sarajevo 1999.

7. Fehim Spaho, "Nekoliko novih podataka o Stocu iz XV i XVI stoljeća," in: Prilozi Or. Filol. 37, 1987, pp. 197-201.

8. Fra M.N. Batinić, "Njekoliko priloga kam bosanskoj crkvenoj poviesti," in: Starine Jugoslovenska Akademija Znanosti i umjetnosti, XVII, Zagreb 1885, pp. 77 - 150. The original is: Codex 218 in the Archivio di Propaganda Fide, Rome, (from p. 480 onward).

9. H. Djurić, “Ali Paša-Stočanin, Hercegovački vezir,” in: Godišnjica Nikole Čupića XLVI, Beograd 1937, pp. 201 - 296.

10. H. Šabanović, Evlija Čelebija Putopis, II, Sarajevo 1957.

11. Hamdija Kapidžić, "Stolac u XVIII vijeku," in: Gajret, Kalendar za godinu 1941, Sarajevo 1940, pp.126 -143.

12. Hamdija Kreševljaković, Kapetanije u Bosni i Hercegovini, Sarajevo (2 ed., 1980).

13. Hauptmann Gustav Thoemmel, "Bescheibung des Vilayet Bosnien, which is Bosnia proper, alongside Turkish Croatia, the Hercegovina and Rascia, Vienna 1867," pp. 131132.

14. Hivzija Hasandedić, Muslimanska Baština u Istočnoj Hercegovini, Sarajevo, 1990.

15. Ibn ül-Emin Mahmud Kemal İnal, Son Asır Türk Şairleri, I, Istanbul 1969.

16. İslâm Ansiklopedisi (Türkiye Diyanet Vakfi), vol 17, İstanbul 1998, pp. 233-235 (for Arif Hikmet).

17. Izet Rizvanbegović, "The results of former archaeological researches at the medieval fortress Vidoška Tvrdjava at Stolac.” in: Balcanoslavica VIII, Beograd 1979, pp. 77 - 92.

18. Izet Rizvanbegović, "Vakufname i Vasijetnama Ali-Paše Rizvanbegovića Stočevića," in: Prilozi Or. Fil, 52/53, Sarajevo 2005, pp. 295 - 328 (with a 17-page facsimile of the original Ottoman text).

19. M.J. Dinić, "Zemlje hercega Sv. Save," in: Glas Srpske Kraljevske Akademije 182, pp. 182-184. Lamenta de foris mentions on 18 February 1444 "Vidoški Grad" (Vego, Naselja, p. 125).

20. Mato Njavro -Sulejman Balić, Herzegovina, Geschichte, Kultur, Naturschönheiten, Zagreb 1985.

21. Mehmed Mujezinović, Islamska Epigrafika Bosne i Hercegovine, III, Sarajevo 1982.

22. O. Knezović, “Ali Paša Rizvanbegović-Stočević, hercegovački vezir 1832-1851,” in: Glasnik Zemaljskog Muzeji XI, 2 Sarajevo 1928, pp. 11-53.

23. Salih Trako - Lamija Hadžiosmanović, "Izbor Gazela iz Divana Arif Hikmet-Bega Rizvanbegovića-Stočevića," in: Prilozi 52/53, 2004, pp. 329-338.

24. Salih Trako en Lejla Gazić, "Dvije Mostarske Medžmue," in: Prilozi Or. Fil. 38, 1988, pp. 97-124. The original is: R. 4287 in the Orientalni Institut in Sarajevo. During the Serbian bombardment of 1992 many manuscripts were stored in an iron case. R.4287 sat in the middle of the case. As a result of the great heath the edges of our manuscript turned black but the core of the book survived in good shape as I could see my self in Juli 2001.

25. Torsten Kolind, "Non-Ethnic Condemnation in Post-War Stolac. An Ethnographic Case-Study of Bosnia-Herzegovina," in: Sanimir Resić and Barbara Törnquist-Plewa (eds), The Balkan in Focus, Lund - Riga 2002, pp. 121-134. 